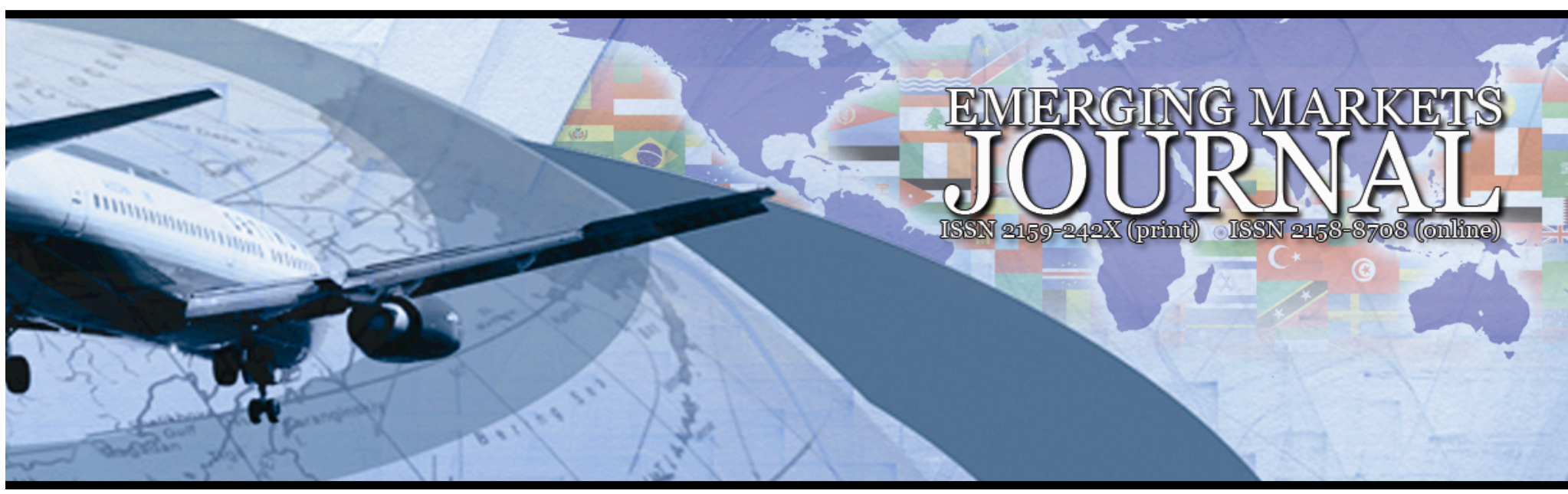

\title{
RE-THINKING ENTREPRENEURSHIP, INTRAPRENEURSHIP, AND INNOVATION: A MULTI-CONCEPT PERSPECTIVE
}

\author{
Mehmet Çağrı Gündoğdu \\ Istanbul University | e-mail: cagri.gundogdu@yahoo.com
}

Volume 2(2012) ｜ＩSSN 2158-8708 (online) ｜ DOI 10.5195/emaj.2012.20 | http://emaj.pitt.edu

\section{Abstract}

This paper aims to show an understanding of the vague issues on the relations among the concepts of entrepreneurship, intrapreneurship and innovation. Some of the greatest intellectual challenges of our time are emerging from the huge study of business management and organization. Through these issues; creating and applying smart ideas that form the practice of business and management, namely entrepreneurial activities, have been noticeably stepping forward for more than three decades. An updated entrepreneurial view in business and management is crucial for reaching the aim of innovation; besides, as it's mentioned above, this perspective deserves to be scrutinized deeply in order to obtain a full understanding of the key concepts of entrepreneurship, intrapreneurship, and innovation also to provide a lean conclusion, which is mainly based on the dual and multi-relations of the related terms. The approach taken in the literature, generally construes entrepreneurship as the main concept regarding entrepreneurial thought; intrapreneurship as its sub-concept; and considers innovation as redundant to include in some of the entrepreneurial definitions; though it's not totally been ignored. However, the new economical framework has proven that a fresh insight is required from now on, in order to explain how to survive in this rapidly changing environment. From this perspective, the main questions of this paper are:

Keywords: Entrepreneurship, Intrapreneurship, Innovation, Innopreneur, Innopreneurship

\section{(cc) BY-NC-ND}

This work is licensed under a Creative Commons Attribution-Noncommercial-No Derivative

Works 3.0 United States License.

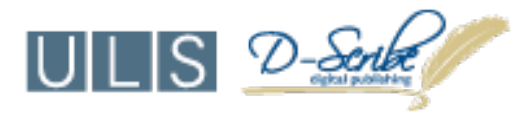

This journal is published by the University Library System of the University of Pittsburgh as part of its D-Scribe Digital Publishing Program, and is cosponsored by the University of Pittsburgh Press 


\section{Re-Thinking Entrepreneurship, Intrapreneurship, and Innovation: A Multi-Concept Perspective}

\author{
Mehmet Çağrı Gündoğdu
}

\section{Introduction}

No managerial system or organization can properly be understood unless it is set in its fundamental and conceptual contexts. Any explanation and understanding of what an entrepreneurial idea is, and what it has and has not achieved, must recognize this. There is not much doubt about the concepts of entrepreneurship, intrapreneurship and innovation in terms of being mutually inclusive. Understanding each of these trending topics of business management and organization study in an integrative view; will certainly make valuable contributions to the existing accumulated knowledge in this discipline and also to the practitioners by highlighting the obscure issues throughout the related subject. Acquiring the capability of explaining the core of the abovementioned key concepts; will provide the essentials to the actors of this career, which they will necessarily be using in the field. The emphasis on the collaboration of the academy and the business world in this context, takes place in the hub. Stemming from the fact that the traditional definition of entrepreneur and intrapreneur has become insufficient in the new economy; it seems to be obligatory to broaden these concepts. The term new economy, as Koçel mentions; implies the qualitative and quantitative changes in the structures and operations of enterprises which are the significant units of the economy, beginning from the mid-80's [1]. The traditional entrepreneur shall now act as an innovation hunter to proactively be able to set up new smart businesses; ideally from the beginning, till the end of any business life cycle. In addition to this, she/he shall persistently continue in this attitude to jump-start innovation in her/his existing enterprise. In our time; finding the capital and taking the risk self-confidently are essential but not sufficient...As Martha Beck underlines; "Any transition serious enough to alter your definition of self will require not just small adjustments in your way of living and thinking but a full-on metamorphosis [2]." Inspirationally, it's seen to be inadequate to stay as a traditional entrepreneur in order to survive on the change island. Considering the incredible progress in information and communication technologies and the new globalized economic framework as a natural outcome; enterprises of our time are like the inhabitants of an island on which everything changes very rapidly. Pursuing this metaphorical manner; sustainable competitive advantage is somewhere very deep below the ocean. In order to dig it up; some capabilities, more than entrepreneurship and intrapreneuship can achieve, are required. In this paper, a new concept called innopreneurship is introduced together with its performing actor, innopreneur. In addition to her/his existing characteristics of a traditional entrepreneur, an innopreneur also has the skills of an intrapreneur to successfully widen the business, besides; she/he is able to act as a vanguard in terms of openness to change, orientation to innovation, proactively scanning the environment, dynamic capability of manoeuvring with implications to adaptation, and having the vision of a transformational leader. Moreover, prudence is certainly fundamental while conversional activities are being conducted.

Contemporarily, enterprises are getting smaller. This is the unavoidable result of the new economy in which, customer needs and expectations are complex and shift sharply. Small and Medium Sized Enterprises (SMEs), as mentioned in the global paradox, are the potential stars of this new economic model. The global 
paradox describes SMEs, as the strengthening small actors of the growing world economy [3]. SMEs shall take advantage of this new conjuncture stemming from the fact that they create much convenience for the customers by their ability to adapt more quickly to dynamic internal and external environmental changes. Because of their nature, they are able to communicate more effectively with customers. Thus, they can fulfill customer needs before their larger competitors in the market can. On the other hand; it's significant for SMEs to adopt and implement proactive strategies, while being aware of the opportunities and threats inside and outside the market. Instead of considering sustainable competitive advantage as a dedicational goal that should be obtained at the end of the day; it's the innopreneurial mind-set which is primarily more critical and will naturally take us to sustainable competitive advantage in the long-run. The innopreneurial mind-set will be discussed later in the section 2.4 of this paper which is about innopreneuring. Now, entrepreneurship in its traditional context will be examined first, and then, intrapreneurship will connectedly be forthcoming.

\section{Literature Review Education}

\section{Entrepreneurship}

The idea of one's doing her/his own business in simple context, has always been perceived as attractive not only by the academicians but also by the employees working in any job and no matter what level or where they're working at. More clearly, many people are concerned with either being an entrepreneur or understanding who entrepreneurs are and what they do; in order to witness their charming but challenging world.

The term entrepreneur, etymologically originates from the French word entreprendre meaning "to begin something, undertake." During the mediaeval times, this word was being used to describe an active working person [4]. However, in the economic theory, it was Richard Cantillon (1759), -an Irish economist of French descent- first, who used the term entrepreneur. According to Cantillon, the entrepreneur is a specialist in taking risk [5]. Risk-taking is one of the famous attributes of entrepreneurs which is also frequently emphasized in the literature. Spiritually, some people are observed to tend to behave extraordinarily. As Jobs addresses; "You have to trust in something-your gut, destiny, life, karma, whatever-because believing that the dots will connect down the road will give you the confidence to follow your heart, even when it leads you off the well-known path, and that will make all the difference [6]." Taking the risk phenomenon and the spiritual reflections into consideration; it can easily be summed up that entrepreneurship has something to do with inner-journey.

Another emphasis on entrepreneurship is its presentation as a mind-set. "Entrepreneurship is first and foremost a mind-set. To seize an entrepreneurial opportunity, one needs to have a taste for independence and self-realization." said Olli Rehn, a member of the European Commission [7]. Understanding the entrepreneurial mind-set requires a certain threshold of empathy. First of all, entrepreneurship is the story of ambiguity. An anonymous supporting quote is likely to highlight the gist of entrepreneurship. It's as follows: "Anyone, (can be an entrepreneur) who wants to experience the deep, dark canyons of uncertainty and ambiguity; and who wants to walk the breathtaking highlands of success. But I caution, do not plan to walk the latter, until you have experienced the former [8]." In this regard, as Schumpeter also points out; entrepreneurs seem to have some heroic vision. Schumpeter focused on high-level entrepreneurship, and larger businesses [9]. On the other hand, Marshall examined smaller businesses, partially [10]. It was Hayek and Kirzner, who examined the entrepreneurs as middlemen hoping to profit by buying cheap and selling expensive [11]. This preference of discussing entrepreneurship inside smaller boundaries is closer 
to the intent of this paper which will be clarified in the upcoming sections. Stopford and Baden-Fuller considered entrepreneurs as opportunists even in chaotic situations, and they also approached to entrepreneurship in a metaphorical way. According to them, entrepreneurs are like Olympic athletes, long-distance runners, symphony orchestra conductors, and top-gun pilots...These metaphors underline the entrepreneurs' being ambitious, determined, self-challenging and talent of synchronizing [12].

When it comes to define entrepreneurship; it can easily be discovered that various people have defined entrepreneurship differently. In spite of this fact, the most common classification follows the mainstream of Collins and Moore; who claimed two types of entrepreneurship, differentiating due to the context of entrepreneurial activities undertaken. These are, firstly, independent entrepreneurship and independent entrepreneurs (similar to entrepreneurship/traditional entrepreneurship and entrepreneurs/traditional entrepreneurs in this paper), implying the process whereby an individual or a group of individuals, acting independently of any association with an existing organization, create a new organization [13]. Secondly, corporate entrepreneurship and administrative entrepreneurs (similar to intrapreneurship and intrapreneurs in this paper), implying the process whereby an individual or a group of individuals, in association with an existing organization, create a new organization or instigate renewal or innovation within that organization [14]. A brief definition of an entrepreneur, inspired by Kuratko, can be made as the following: An entrepreneur is an undertaker who notices and seizes opportunities; converts those opportunities into commercial ideas; adds value via processes, effort, capital, or capabilities; and confronts the risks of the competitive market to apply those ideas; and what an entrepreneur accomplishes, is therefore called entrepreneurship [15]. Now, entrepreneurial activities within an existing organization, namely intrapreneurship will be discussed.

\section{Intrapreneurship}

The study of intrapreneurship, implying entrepreneurial activities conducted within existing organizations, has expanded over the last three decades [16]. Most research in this field, has focused on the possibility; that managers and individual employees could be inspired to behave entrepreneurially; create innovations, and obtain profit and growth through these innovations [17], [18], [19], [20], [21]. This is about a powerful foresight that managers and their organizations can form an ambience that fosters to create and manage new businesses within existing organizational framework [22], [23], [24].

Scholars have shown the tendency to divide entrepreneurship into two sub-titles according to its operating context. On one hand, it's common to use entrepreneurship or independent entrepreneurship to describe entrepreneurial efforts of individuals operating outside the context of an existing organization. On the other hand, different terms can be seen in the literature implying the entrepreneurial efforts within an existing organization such as corporate entrepreneurship as Burgelman and Zahra used respectively in their separate studies; corporate venturing which Biggadike mentioned; Pinchot's intrapreneuring ; internal corporate entrepreneurship of Jones and Butler; Schollhammer and Vesper's internal entrepreneurship; Guth and Ginsberg's strategic renewal and venturing of Hornsby, Naffziger, Kuratko, and Montagno [25], [26], [27], [28], [29], [30], [31], [32]. Here, only intrapreneurship is being used for common purpose, referring more likely Pinchot's view of defining intrapreneurs as the "dreamers who do"; those who take hands-on responsibility for creating innovation of any kind within an existing organization [33]. Innovation is the next topic to be examined.

\section{Innovation}

Innovation, has emerged as a headline in the field of business management, recently. Kuratko determines the magic words to describe the new 
innovation way of our time: Dream, create, explore, invent, pioneer, and imagine [34]. Innovation itself is undergoing change [35].

The etymological roots of innovation stretch to the Latin word innovare, meaning to do something new [36]. Most of the innovation definitions, have focused on similar points with different perspectives. The key common points imply change and renewal for a better situation. The Organization for Economic Cooperation and Development (OECD), inside the Oslo Manualthe source of information regarding international technological developments- defines innovation by linking it to technological change. According to OECD, innovation means "completing products and services by developing them technologically [37]. The European Union (EU) has made a broader definition. To EU, innovation introduces the change in workforce talent, working conditions, managerial and organizational jobs. Also, it's about renewal and growth in product and service range [38]. In addition to this, a well-known expression about innovation; characterizes it as the process of converting new ideas into value-creating outputs such as new products, methods or services. By the help of innovation; companies acquire the ability to develop and apply not only new products, processes or designs but also new operation and business models [39].

After having experienced enormous financial crises all over the world in recent years; company survival has emerged as the most crucial issue both for SMEs and even some of large companies [40]. As mentioned in the introductory part of this paper, SMEs, as the increasing value of the new economy, are obligatorily undertaken the mission of being innovative. It's innovative SMEs which will lead the way to economic recovery. Now, the innopreneurial thought will be scrutinized in the light of entrepreneurship, intrapreneurship and innovation.
A Prototype Emerging From the New Economy: The Innopreneur- Beyond the Optimum Synthesis of Entrepreneur, Intrapreneur and Innovation

It has been long, having dispelled the myth that "the entrepreneurs are born, not made." Drucker confirms this opinion regarding entrepreneurial thought: "Most of what you hear about entrepreneurship, is all wrong. It's not magic; it's not mysterious; and it has nothing to do with genes. It's a discipline and, like any discipline, it can be learned [41]." Likely, innopreneurship, can be learned via education, training programmes, strategy formulation and a well-comprehended strategic management view. Undoubtfully, a certain level of enterprising talent is underlying.

It's not a desired outcome to be thought that the traditional entrepreneurs will totally be eliminated because of the new emerging character, innopreneur. But, it's true for traditional entrepreneurs, who take the risk and invest the capital in a self-confident manner, that they should remedy themselves by making the necessary adjustments; to become an innopreneur.

Like the organizations being exposed to entropy; traditional entrepreneurs are facing the danger of being pushed to the outside of the system. The concept of entropy implies the tendency which exists in every system; toward the exhaustion of energy, losing the balance, disorder, and finally leading to demise of the system [42]. Besides; negative entropy, which is possible in open systems (biological and social systems which interact with the environment), means preventing the negative effects of entropy with the help of knowledge, energy and materials taken from the environment [42]. In biological systems, entropy may cause death; and in social systems like enterprises, it may cause all the operations to stop, ultimately [42]. In order to make it reverse, and maintain sustainable competitive advantage; traditional entrepreneurs should transform themselves into innopreneurs. 
The increasing significance of SMEs as the main constituents of the new economy, was emphasized in the beginning of this paper. Innopreneurs; as the steering leaders of SMEs in this new economic framework, while protecting the traditional values and traits of entrepreneurs; will have to reach beyond. Innopreneurs should constantly enter into positive change and make efforts for innovation. They should continuously update and develop themselves also intra-business, maintaining the aspects of being an intrapreneur.

Entrepreneurial factors like capital, self-confidence, motivation for the start-up, commitment to business, optimism, managerial skills, leadership characteristics are certainly also valid for innopreneurship. It would be acting unjustly to traditional entrepreneurs by saying that the above-mentioned attributes are unimportant. Indeed, entrepreneurship is at the core. It's a strong pillar of the business and management discipline, on top of which, innopreneurship is builded. Innopreneurs can be made. Entrepreneurs can learn to become innopreneurs with the help of education and training. An innopreneur has the ability of leading to innovation. So, she/he has the characteristics of an innovative leader in this regard. She/he is also an effective manager to accomplish the business. It's not an absolute necessity for an innopreneur, to apply hands-on-management in every step of the business. Whatever the case is; the innopreneur's leading role stays constant.

It's noteworthy; that every innopreneur is also an entrepreneur but not every entrepreneur can be classified as an innopreneur. Our goal is, achieving the utopia of transforming every entrepreneur into innopreneurs. Every innopreneur is an innovation-oriented entrepreneur. Every innopreneur, has powerful attempts toward innovative new ventures. Not every entrepreneur makes innovation but every innopreneur does. In this sense, the intrapreneur resembles the innopreneur in terms of innovation-orientation. In spite of this, the intrapreneur differs from the innopreneur in performing environment of innovation. The scope of intrapreneurship is constricted to the existing organizational area. On the other hand, the innopreneur, is not subject to such criteria. The innopreneur performs at a new stage, which is called the new economy. The innopreneur, is a prototype, self-developed to meet the needs of the new economy. The innopreneur is the new evolutionary model, the cumulative advanced type that emerged from this environment. In addition, she/he is the leader who forms the suitable environment; in which the intrapreneurs are empowered, and their ideas and attempts to make innovation are strongly encouraged. While serving as a catalyst, the innopreneur may also take active role in these efforts. Innopreneurship, for now, is a concept dealing with the ideal rather than what exists. It harmonizes its predecessors entrepreneurship, intrapreneurship and the popular concept of innovation through an integrative perspective and fulfills the unique requirements of the new economy.

The innopreneur undertakes to manage, and take the risks of a business model. In our time, an innopreneur is interested in research and development and characterized as an innovation hunter who agressively seeks for opportunities; transforms those opportunities into concrete marketable ideas; creates value-added; makes maximum efforts, assesses and undertakes the relevant risks to apply those ideas; and gathers the crops at harvest time.

\section{III.Conclusion}

The catastrophic advance in the information and communication technologies in the last few decades and the new globalized world economy as a result, caused the enterprises compulsorily get much closer to the customers, respond more quickly to their needs, and dynamically adapt to internal and external environmental circumstances. In such a new order, SMEs, have emerged as the significant actors of the economy. They're the strengthened small actors of 
growing world economy as mentioned in the global paradox. Consequently, in this high-competition environment, management of the SMEs, is appraised as a top-agenda subject. Most of the SMEs are family businesses and the most important handicap of the family businesses is their inadequancy in qualified human resources. Despite SMEs' turning to be the shining stars of the new economy; they are not likely to succeed in this challenging arena with the available traditional entrepreneurs they have, most of whom are lessqualified family members. The solution they need is probably hidden inside the concept of innopreneurship. They need innopreneurs who show talent in adapting to dynamically changing conditions of the environment; responding to evolutionary expectations of customers even simultaneously, getting an inkling of innovation and marketing it in the first place. Moreover, maintaining this position is also crucial for the sake of innopreneurship. Sustainable competitive advantage has emerged to be able to be obtained only by this new type of innovation hunters demonstrating powerful innopreneurial attitude. In other words, the enterprises of our time are gradually downsizing. On the opposite, this fact brings the necessity of an increase in the abilities of the enterprising people who will enter into smart businesses, and drag them with intra-organizational activities. In attribution to the global paradox once again; strengthening small actors (SMEs)' commanders' attributes should be updated and converted into that of innopreneurs'. Taking the famous saying "Either change or die [43]!" into consideration; like the organizations which manage to reverse the danger of entropy to negative entropy; existing traditional entrepreneurs also should turn out as innopreneurs not to face the danger of being isolated outside the system.

Up to now; capital, risk-taking, and selfconfidence have been the dominant characteristics of a business starter, called an entrepreneur. However, today, these attributes help maintaining an enterprise only for a certain period of time which is not very long. Yes, it has been known that owning the ship has never made the owner, the captain. But things have changed; and this mission is attributed to the Great Innopreneur. As a concluding remark, only owning the ship doesn't make traditional entrepreneur the captain. The aim of this paper is to point out the obligation of traditional entrepreneurs; to evolve and become the captains, who are capable of floating their ship on the new economical ocean. Who knows what the tide could bring for the innopreneurs of the change island $[44]$ ? 


\section{IV.References}

1. Koçel, T., (2007), İşletme Yöneticiliği, 11.Bası, Arıkan Basım Yayın, Istanbul.

2. Beck, M., (2004), O Magazine, Growing Wings, January.

3. Koçel, T., (2007), İşletme Yöneticiliği, 11.Bası, Arıkan Basım Yayın, Istanbul.

4. TÜSİAD, (2002), Türkiye'de Girişimcilik, İstanbul: TÜSİAD Yayını.

5. Cantillon, R., (1755), Essai sur la nature du commerce en generale (ed.Henry Higgs, 1931), London: Macmillan.

6. Jobs, S.P., (2005), American businessman and inventor, Stanford Commencement Speech, USA.

7. Lundström, A. and Stevenson, L.A., (2010), Entrepreneurship Policy, Theory and Practice, Springer, USA.

8. Timmons J. A., and Spinelli S., (2007), New Venture Creation, Seventh Edition. New York: McGrawHill/Irwin.

9. Schumpeter, J.A., (1934), The Theory of Economic Development (trans. Redvers Opie), Cambridge, MA: Harvard University Press.

10. Marshall, A., (1919), Industry and Trade, London: Macmillan.

11. Hayek, Friedrich A. von, (1937), Economics and Knowledge, Economica (New ser.).

Kirzner, Israel M., (1973), Competition and Entrepreneurship, Chicago: University of Chicago Press.

12. Stopford, J.M. and Baden-Fuller, C.W.F., (1994), Creating Corporate Entrepreneurship, Strategic Management Journal, 15(7), 521-536.

13. Collins, O. and Moore, D.G., (1970), The Organization Makers, New York Appleton.

14. Collins, O. and Moore, D.G., (1970), The Organization Makers, New York Appleton.

15. Kuratko, D.F., (2009), Introduction to Entrepreneurship, Eigth Edition, South-Western Cengage Learning, Canada.

16. Sathe,V., (2003), Corporate Entrepreneurship: Top Managers and New Business Creation, Cambridge, UK: Cambridge University Press.

17. Block, Z.and MacMillan, I.C., (1993), Corporate Venturing: Creating New Businesses Within the Firm, Boston, MA: Harvard Business School Press.

18. Bowman, C., (1999), "Why We Need Entrepreneurs, Not Managers?", General Management Review, 1(1), $15-23$.

19. Brazeal, D.V., (1993), “Organizing for Internally Developed Corporate Ventures”, Journal of Business Venturing, 8(1), 75-90. 
20. Morris, M.H., (1998), Entrepreneurial Intensity, Westport, CT: Quorum Books.

21. Sathe, V., (2003), Corporate Entrepreneurship: Top Managers and New Business Creation, Cambridge, UK: Cambridge University Press.

22. Morris, M.H., (1998), Entrepreneurial Intensity, Westport, CT: Quorum Books.

23. Munk, N. (1998), “The New Organization Man”, Fortune, 16 March, 68-72.

24. Pinchot, G. III., (1985), Intrapreneuring, Harper \& Row, New York.

25. Burgelman, R.A., (1983), Corporate Entrepreneurship and Strategic Management Insights from a Process Study Management Science, 29, 1349-1364.

26. Zahra, S.A., (1993), A Conceptual Model of Entrepreneurship as Firm Behavior, A Critique and Extension, Entrepreneurship Theory and Practice, 17(4), 5-21.

27. Biggadike, R., (1979), The Risky Business of Diversification, Harvard Business Review, 57(3), $103-111$.

28. Pinchot, G. III., (1985), Intrapreneuring, Harper \& Row, New York.

29. Jones, G.R., and Butler, J.E., (1992), Managing Internal Corporate Intrapreneurship: An Agency Theory Perspective, Journal of Management, 18, 733-749.

30. Schollhammer, H., (1982), Internal Corporate Entepreneurship, In Kent, C.A., Sexton, D.L., and Vesper, K.H.(Eds.), Encylopedia of Entrepreneurship, pp.209-229, Englewood Cliffs, NJ, Prentice Hall.

31. Guth, W.D., and Ginsberg, A., (1990), Guest Editors' Introduction, Corporate Entrepreneurship, Strategic Management Journal, 11(Summer), 5-15.

32. Hornsby, J.S., Naffziger, D.W., Kuratko, D.F., and Montagno, R.V., (1993), An Integrative Model of the Corporate Entrepreneurship Process, Entrepreneurship Theory and Practice, 17(2), 29-37.

33. Pinchot, G. III., (1985), Intrapreneuring, Harper \& Row, New York.

34. Kuratko, D.F., (2009), Introduction to Entrepreneurship, Eigth Edition, South-Western Cengage Learning, Canada.

35. Nicol, T., (2010), The Innovation Handbook, How to profit from your ideas, intellectual property, and market knowledge, Second Edition, Kogan Page, Great Britain and the United States

36. Clapham, M.M., (2003), “The Development of Innovative Ideas through Creativity Training”, International Handbook on Innovation, ed.Larisa V. Shavinina, London: Pergamon.

37. OECD and European Commission, (1997), Proposed Guidelines for Collecting and Interpreting Technological Innovation Data: The Oslo Manual, Paris: OECD.

38. European Commission, (1995), Green Paper on Innovation, COM (1995) 688, Brussels: European Commission.

Re-Thinking Entrepreneurship, Intrapreneurship, and Innovation: A Multi-Concept Perspective 
39. Webb, R., (2010), The Innovation Handbook, How to Profit from Your Ideas, Intellectual Property, and Market Knowledge, Second Edition, Kogan Page, Great Britain and the United States.

40. Webb, R., (2010), The Innovation Handbook, How to Profit from Your Ideas, Intellectual Property, and Market Knowledge, Second Edition, Kogan Page, Great Britain and the United States.

41. Drucker, P., (1985), Innovations and Entrpreneurship. New York Harper \& Row

42. Koçel, T., (2007), İşletme Yöneticiliği, 11.Bası, Arıkan Basım Yayın, Istanbul.

43. Beer, M. and Nohria, N., (2000), “Cracking the Code of Change.”, Harvard Business Review, 78(3), pp.133141.

44. Hanks, T. as Noland, C., (2000), Cast Away, A drama film directed by Zemeckis, R. , and starring Hanks, T., Twentieth Century Fox International Dreamworks, USA. 